\title{
TYPHETUM LAXMANNII (UBRIZSY 1961) NEDELCU 1968 - THE NEW PLANT ASSOCIATION IN POLAND
}

\author{
MARCIN NobIS ${ }^{1}$, AGNIESZKA NoBis ${ }^{1}$, ARKADIUSZ NOWAK ${ }^{2}$ \\ ${ }^{1}$ Department of Plant Taxonomy and Phytogeography \\ Institute of Botany, Jagiellonian University \\ Kopernika 27, 31-501 Kraków, Poland \\ e-mail: nobis@fagus.ib.uj.edu.pl \\ 2 Department of Biosystematics, \\ Division of Geobotany and Plant Conservation \\ University of Opole \\ Oleska 22, 45-052 Opole, Poland
}

(Received: March 3, 2006. Accepted: June 6, 2006)

\begin{abstract}
Typhetum laxmannii (Ubrizsy 1961) Nedelcu 1968 is a plant association new to Poland, built by an expansive kenophyte - Typha laxmannii Lepech. This paper presents the general distribution of both, the species and the association, paying particular attention to the area of Europe and Poland where, in recent years, many new locations as well as an increasing participation in vegetation cover have been observed. The habitat preferences of Typhetum laxmannii, the floristic composition of the association and its geographical differentiation within the occupied area are described. The current distribution of the association in Poland is presented on the cartogram map $10 \times 10$ $\mathrm{km}$ and possible expansion routes are suggested.
\end{abstract}

KEY WORDS: Typhetum laxmannii, anthropogenic habitats, rush communities, numerical analysis, kenophytes, distribution, Poland.

\section{INTRODUCTION}

The occurrence and expansion of the plant species in areas where they have not been present before (in many cases far away from their native range) are not an extraordinary phenomenon in a biotic world and are mainly connected with the direct influence of human activity. The alien species appear mostly incidentally, so their status in regional floras is ephemerophyta (Kornaś 1981). However, there are species with high adaptive potential, which can, in a relatively short time, adjust to new ecological conditions and afterwards expand or even invade new areas and habitats. In some cases the expanding alien species play an important role in the composition of native associations or build their own, xenospontanic phytocenoses (Faliński 1969). Only a few non-native species build their own plant communities in the territory of Poland. As an example for wetland habitats could serve Elodea canadensis Mchix. building the association Elodeetum canadensis (Ping. 1953) Pass. 1964, Acorus calamus L. creating the rush association Acoretum calami Kobendza 1948 and some other plants making a relatively significant contribution to native vegetation (Matuszkeiwicz 2001). This group of alien species also includes a plant which is one of the newest elements in the Polish flora - Typha laxmannii Lepech. buil- ding recently the new anthropogenic plant association Typhetum laxmannii (Ubrizsy 1961) Nedelcu 1968.

\section{THE GENERAL DISTRIBUTION OF TYPHA LAXMANNII LEPECH.}

Typha laxmannii is a species belonging to the Euro-Siberian sub-element. In Asia its locations are known from the Chinese provinces of Heilongjiang, Jilin, Jiangsu, Liaoning, Heibei, Henan, Shanxi, Shangdong, Qinghai, Gansu, Sichuan, municipalities of Ningxia, Xinjiang and InnerMongolia, as well as from Pakistan, Afghanistan, Tajikistan, Mongolia, Azerbaijan, Kazakhstan, Siberia, Mid-Ural Mts., Iran, Turkey (Fiala, Jankovská 1968 and there cited lit.; Klokov, Volkova 1988; Yu-Long Feng pers. comm.).

In Europe, the status of the species is uncertain. According to some authors, it most likely occurs naturally in Bulgaria, Romania, Ukraine and in the south-western part of Russia (Cook 1980; Prokubin 1987; Schmalhausen 1897). Others suggest that the species had been unintentionally introduced to Mediterranean regions of Europe from Asia with rice cultivation (Stojanov, Stefanov 1948; Ubrizsy 1961), and afterwards began its expansion north- and westwards. Currently, Typha laxmannii is quite broadly di- 
stributed in the Czech Republic and Slovakia, e.g. in Košice surroundings, in Beskid Niski Mts. and in the Slovakian Carst area (Fiala, Jankovská 1968; Čvančara, Šourková 1973; Dostál 1978; Rozloznik 1998). The species has also been observed in Germany (Oberdorfer 1990; Haeupler, Muer 2000), Hungary (Fekete et al. 1997), Slovenia (Kaligarič and Jogan 1996), France (Guinochet, de Vilmorin 1978; Bissardon 2000), in northern and central Italy (Pignatti 1982; Morisi 1998, 2001; Ori, Alagna 2004), Croatia (Topic, Ozimec 2001), and Greece (Halacsy 1902; Hayek 1932-1933; Sarika et al. 2005). In Ukraine Typha laxmannii occurs in the coastal area of the Black Sea and northwards alongside the Dniestr river basin in artificial canals (Balashev, Parakhonskaja 1977).

In the area of Poland Typha laxmannii has been known since 1988, but the first published information about its appearance is included in the work of Czylok, Baryła (2003), and the distribution of the species was presented by Baryła et al. (2005). Until now, the locations of Typha laxmannii have been reported from Opole Silesia (Nowak 2004); Upper Silesia (Baryła et al. 2005; Woch 2005), Western Carpathians (Baryła et al. 2005; Beczała et al. 2005) and from the Małopolska Upland and Sandomierz Basin (Baryta et al. 2005). During the field studies conducted by the authors of this paper, four new localities of Typha laxman$n i i$ were found (they are listed below in the Typhetum laxmannii register). Presently, in the area of Poland, 29 locations of the species are known, and it is possible to find other new localities in near future. The current distribution map of Typha laxmannii in Poland using the ATPOL grid squares $10 \times 10 \mathrm{~km}$ is presented in Figure 1.

\section{THE CHARACTERISTICS AND DISTRIBUTION OF TYPHETUM LAXMANNII}

At first the community with the dominance of Typha laxmannii was described in syntaxonomical classification as a subassociation - Scirpeto-Phragmitetum subass. typhosum laxmannii Ubrizsy 1961 (Nedelcu 1967). Later phytosociological analysis allowed the rank of the community to be raised to an autonomous association - Typhetum laxmannii (Ubrizsy 1961) Nedelcu 1968 (Nedelcu 1968, 1969). In southern and eastern Romania, Typhetum laxmannii occurs on watersides of rivers and reservoirs and also in rice fields, which are occasionally flooded to the maximum depth of $10-15 \mathrm{~cm}$, e.g. in spring. During the summer and autumn, the habitats remain moist or dry (Nedelcu 1969; Popescu et al. 1969). In the Czech Republic and Slovakia the association has been noticed in riverside habitats, channels and fish-ponds as well as in artificial excavations like sand or gravel-pits and in quarries (Ot'ahel'ová et all 2001). The basic physic-chemical characteristic of the waters was given for the flooded areas of the Dudu and Ipel rivers. The water $\mathrm{pH}$ index oscillates between (7.05) 7.10 and 8.30 (Nedelcu 1968; Hrivnák 2004). In such conditions the characteristic species is dominant, covering $50-80 \%$ of the community patch area and it occurs

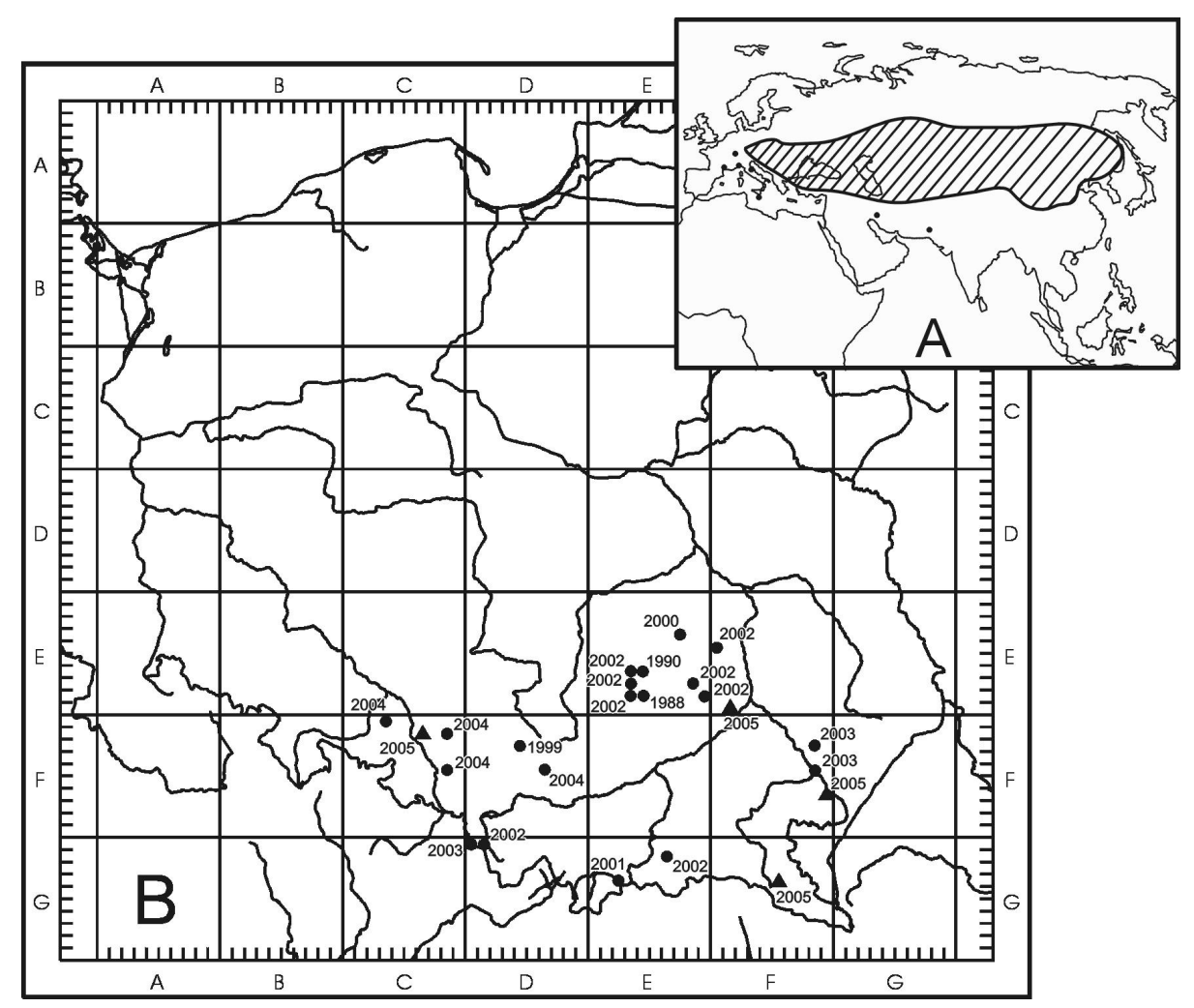

Fig. 1. Distribution map of Typha laxmannii Lepech. A - the general range according to Fiala, Jankovská (1968) - supplemented; B - local range in Poland, in ATPOL grid 10×10 km according to Baryła et all (2005) - changed and supplemented. $\boldsymbol{\Delta}$ - new locations. The locations are accompanied by the year of discovery. 
TABLE 1. Typhetum laxmannii (Ubrizsy 1961) Nedelcu in Poland.

\begin{tabular}{|c|c|c|c|c|c|c|c|c|c|c|c|c|c|c|c|c|c|c|c|c|c|c|c|c|c|}
\hline \multicolumn{2}{|c|}{ Relevé number } & 1 & 2 & 3 & 4 & 5 & 6 & 7 & 8 & 9 & 10 & 11 & 12 & 13 & 14 & 15 & 16 & 17 & 18 & 19 & 20 & 21 & 22 & 23 & \\
\hline \multirow{2}{*}{\multicolumn{2}{|c|}{$\begin{array}{l}\text { Localization } \\
\text { day }\end{array}$}} & Grze & Wys & Zgo & Klim & Zgo & Gór & Zach & Zach & Kow & Kow & SO & so & Kot & LT & LT & KŚ & KŚ & Wie & Pig & Wie & Wie & Wie & Wie & \multirow{8}{*}{ 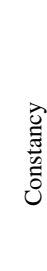 } \\
\hline & & 21 & 14 & 27 & 9 & 27 & 13 & 14 & 14 & 14 & 14 & 24 & 7 & 13 & 13 & 28 & 4 & 13 & 19 & 5 & 14 & 14 & 14 & 14 & \\
\hline & month & 9 & 8 & 7 & 6 & 7 & 8 & 9 & 9 & 9 & 9 & 7 & 8 & 8 & 8 & 7 & 8 & 8 & 6 & 9 & 9 & 9 & 9 & 9 & \\
\hline & year & 2004 & 2005 & 2005 & 2005 & 2005 & 2005 & 2004 & 2004 & 2004 & 2004 & 2004 & 2005 & 2005 & 2005 & 2004 & 2004 & 2005 & 2004 & 2003 & 2004 & 2004 & 2004 & 2004 & \\
\hline \multicolumn{2}{|c|}{ Cover of b (\%) } & - & - & - & - & 5 & - & - & - & - & - & - & - & - & - & 15 & 5 & 5 & - & - & - & - & - & - & \\
\hline \multicolumn{2}{|c|}{ Cover of c (\%) } & 40 & 50 & 60 & 75 & 50 & 90 & 70 & 75 & 85 & 90 & 85 & 85 & 70 & 85 & 85 & 80 & 80 & 70 & 80 & 90 & 90 & 90 & 90 & \\
\hline \multicolumn{2}{|c|}{ Cover of mosses "d" (\%) } & 3 & 5 & 60 & - & - & - & 10 & 10 & 3 & 40 & 20 & 15 & - & - & - & 5 & 5 & 3 & 8 & 50 & 3 & 3 & 20 & \\
\hline \multicolumn{2}{|c|}{ Area of record $\left(\mathrm{m}^{2}\right)$} & 10 & 50 & 15 & 30 & 9 & 50 & 10 & 30 & 6 & 15 & 50 & 50 & 50 & 50 & 50 & 50 & 50 & 150 & 100 & 30 & 15 & 70 & 15 & \\
\hline \multicolumn{2}{|c|}{ Number of species } & 6 & 8 & 9 & 6 & 12 & 7 & 7 & 11 & 17 & 19 & 19 & 17 & 13 & 18 & 20 & 14 & 19 & 10 & 18 & 7 & 11 & 10 & 9 & \\
\hline
\end{tabular}

Ch. Ass. Typhetum laxmannii

\begin{tabular}{|c|c|c|c|c|c|c|c|c|c|c|c|c|c|c|c|c|c|c|c|c|c|c|c|c|}
\hline Typha laxmannii & 3 & 4 & 4 & 5 & 4 & 5 & 5 & 3 & 5 & 2 & 4 & 4 & 3 & 4 & 3 & 4 & 4 & 5 & 5 & 5 & 5 & 5 & 5 & $\mathrm{~V}$ \\
\hline Ch. All. Phragmition & & + & 1 & . & + & + & + & 1 & . & . & . & & 1 & . & . & $\mathrm{r}$ & + & + & 2 & & . & + & . & III \\
\hline Eleocharis palustris & & & . & . & 1 & + & & . & + & & 1 & + & 1 & + & . & & & & 1 & + & . & & . & II \\
\hline Phragmites australis & & . & + & + & & . & & 2 & & & . & + & . & + & + & + & + & & . & & . & & . & II \\
\hline Typha angustifolia & & . & + & + & + & 1 & & . & + & 1 & + & 1 & 1 & + & + & & + & & . & & . & & . & III \\
\hline \multicolumn{25}{|l|}{ Typha latifolia } \\
\hline \multicolumn{25}{|c|}{ Ch. Cl. Phragmitetea et O. Phragmitetalia } \\
\hline Alisma plantago-aquatica & . & + & 1 & + & + & . & + & 2 & + & . & . & $\mathrm{r}$ & + & . & . & + & + & . & . & . & . & . & . & III \\
\hline Schoenoplectus tabernaemontanii & . & . & . & . & . & + & . & . & . & . & 1 & + & . & . & . & . & . & . & . & . & . & . & . & I \\
\hline \multicolumn{25}{|l|}{ Ch. Cl. Isoëto-Nanojuncetea } \\
\hline Centaurium pulchellum & . & . & . & & . & . & . & . & + & + & $\mathrm{r}$ & + & . & . & & + & + & . & & . & & + & . & II \\
\hline Juncus bufonius & . & . & . & . & . & & . & . & . & . & . & . & . & + & 1 & . & + & . & . & . & & . & . & I \\
\hline Plantago intermedia & . & . & . & . & . & & . & . & . & . & + & . & . & + & + & + & + & . & . & . & & + & . & II \\
\hline \multicolumn{25}{|l|}{ Ch. Cl. Molinio-Arrhenatheretea } \\
\hline Daucus carota & . & . & . & . & . & & . & . & + & + & . & . & & & $\mathrm{r}$ & . & . & . & . & . & + & . & . & I \\
\hline Equisetum palustre & . & . & . & . & . & & . & . & . & . & . & . & . & + & + & . & . & . & . & . & + & . & . & I \\
\hline Juncus compressus & . & . & . & . & . & & + & + & . & . & . & + & 1 & + & + & . & . & . & + & . & . & + & . & II \\
\hline Juncus inflexus & . & + & + & + & . & & . & . & . & . & . & . & . & . & . & . & . & . & . & . & & . & . & I \\
\hline Lythrum salicaria & + & + & . & . & . & 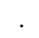 & . & . & . & . & . & . & . & . & . & . & . & . & + & . & & . & . & I \\
\hline \multicolumn{25}{|l|}{ Ch.Cl. Scheuchzerio-Caricetea nigrae } \\
\hline Juncus alpino-articulatus & & & . & & . & & + & + & . & 1 & . & . & & & & . & . & . & & . & . & . & + & I \\
\hline Juncus articulatus & 2 & 2 & 1 & 1 & . & + & . & . & . & + & 1 & 1 & 1 & 1 & 2 & + & 1 & . & + & + & + & + & + & IV \\
\hline \multicolumn{25}{|l|}{ Ch.Cl. Salicetea purpureae } \\
\hline Salix alba "c" & + & + & . & & + & & . & . & . & . & . & . & . & . & & . & . & + & + & . & & . & & II \\
\hline Salix purpurea "c" & . & . & . & & . & . & . & . & . & + & . & . & . & + & & . & + & + & + & + & + & . & & II \\
\hline Salix vimminalis "b" & . & . & . & . & + & . & . & . & . & . & . & . & . & . & & 1 & + & . & & . & . & . & & I \\
\hline \multicolumn{25}{|l|}{ Ch.Cl. Artemisietea vulgaris } \\
\hline Epilobium hirsutum & . & & . & . & . & & . & . & . & . & + & + & + & + & + & + & + & . & . & . & & . & . & II \\
\hline
\end{tabular}




$+\quad+\quad+$

$+$

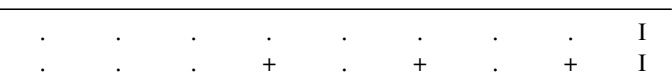

\section{Other species}

Alopecurus aequalis

Bidens tripartita

Calamagrostis epigeios

Chara sp.

Epilobium adenocaulon

Lycopus europaeus

Marchantia polymorpha "d"

Salix caprea "c"

Tussilago farfar

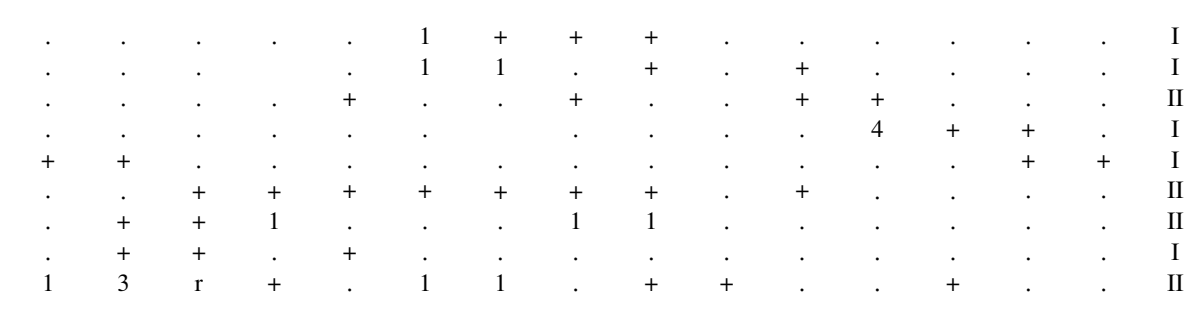

Sporadic species: Ch. Cl. Phragmitetea: Poa palustris 19(+), 23(+); Schoenoplectus lacustris 22(+), 23(+); Ch. Cl. Isoëto-Nanojuncetea: Carex demissa 18(+); Carex viridula 8(+), 2(+); Cyperus fuscus 19(+); Ch. Cl. MolinioArrhenatheretea: Achillea millefolium 14(+), 15(+); Agrostis stolonifera 19(+); Deschampsia caespitosa 11(+); Juncus effusus $5(+)$; Leontodon autumnalis $8(+)$; Lotus corniculatus $9(+), 10(+) ;$ Myosotis palustris $11(+), 12(+)$; Plantago lanceolata $9(+)$; Plantago maior 10(+); Prunella vulgaris 14(1), 15(+); Ranunculus repens $3(+)$; Rumex crispus $9(+)$; Taraxacum officinale s. 1. 7(+); Trifolium repens $9(+)$, 10(+); Ch.Cl. Scheuchzerio-Caricetea nigrae: Carex flava 11(+), 12(+); Epipactis palustris 18(+); Veronica scutellata 19(+); Ch.Cl. Salicetea purpureae: Salix purpurea "b" 5(1), 15(2); Salix vimminalis "c" 6(+), 13(+); Ch.Cl. Artemisietea vulgaris: Cirsium arvense 23(+); Melilotus albus 10(+); Tanacetum vulgare 5(+); Inne: Agrostis vulgaris 10(+); Brachyactis ciliata 9(2), 10(2); Brachytecium rutabulum "d" 11(1), 12(2); Bryum bicolor 7(1); Bryum pseudotriquetrum 18(+);

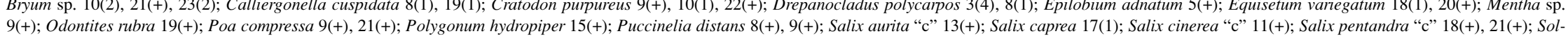
idago graminifolia $11(+)$

Locality of the relevés: 1 - chalk-pit Skały near Grzegorzowice, SE from Kielce; 2 - chalk-pit Kożuszne near Wysoczany village (N from Komańcza); 3, 5 - out of work sand pit, NE part of the Zgoda village near Jarosław; 4 - excavationes in E part of Klimontów near Sandomierz; 6 - marl quarry, Górażdże near Opole; 7, 8 - out of work quarry, Zachełmie near Kielce; 9, 10 - still in operation chalk-pit, Kowala near Kielce; 11, 12 - out of work marl quarry in Strzelce Opolskie; 13 - sand pit in Kotlarnia near Opole; 14, 15 - basalt quarry in Ligota Tułowicka near Opole; 16, 17 - marl quarry in Kamień Śląski near Opole; 18, 19, 20, 21, 22, 23 - marl quarry, W from Wierzbica near Radom; 19 - sand pit in Pigany near Sieniawa.
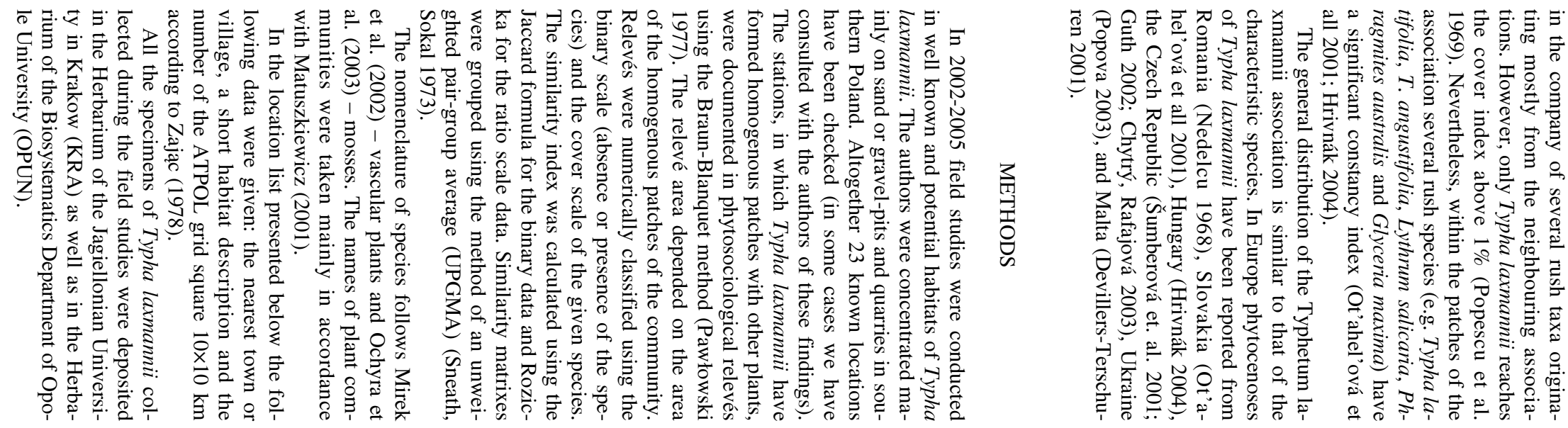
TABLE 2. Quantitative participation of characteristic, differential and sporadic species in the patches of Typhetum laxmannii (Ubrizsy 1961) Nedelcu 1968 in Poland.

\begin{tabular}{|c|c|c|c|c|c|c|c|c|c|c|}
\hline \multicolumn{11}{|c|}{ Number of relevés -23} \\
\hline \multirow{2}{*}{ Species } & \multicolumn{7}{|c|}{ Cover ratio } & \multirow{2}{*}{\multicolumn{2}{|c|}{ Constancy }} & \multirow{2}{*}{ Cover index } \\
\hline & 5 & 4 & 3 & 2 & 1 & + & $\mathbf{r}$ & & & \\
\hline \multicolumn{11}{|l|}{ Ch. Ass. Typhetum laxamannii } \\
\hline Typha laxmannii & 10 & 8 & 4 & 1 & . & . & . & V & 100 & 6706 \\
\hline \multicolumn{11}{|l|}{ Differential species } \\
\hline Juncus articulatus & . & . & . & 3 & 7 & 8 & . & IV & 78 & 398 \\
\hline Eleocharis palustris & . & . & . & 1 & 3 & 7 & 1 & III & 52 & 157 \\
\hline Typha latifolia & . & . & . & . & 4 & 8 & . & III & 52 & 104 \\
\hline Alisma plantago-aquatica & . & . & . & 1 & 1 & 8 & 1 & III & 48 & 115 \\
\hline Phragmites australis & . & . & . & . & 4 & 5 & . & II & 39 & 98 \\
\hline Tussilago farfara & . & . & 1 & . & 3 & 4 & 1 & II & 39 & 237 \\
\hline Typha angustifolia & . & . & . & 1 & . & 7 & . & II & 35 & 91 \\
\hline Juncus compressus & . & . & . & . & 1 & 7 & . & II & 35 & 37 \\
\hline \multicolumn{11}{|l|}{ Accompanying species } \\
\hline Lycopus europaeus & . & . & . & . & . & 8 & . & II & 35 & 17 \\
\hline Salix purpurea "c" & . & . & . & . & . & 7 & . & II & 30 & 15 \\
\hline Epilobium hirsutum & . & . & . & . & . & 7 & . & II & 30 & 15 \\
\hline Centaurium pulchellum & . & . & . & . & . & 6 & 1 & II & 30 & 13 \\
\hline Plantago intermedia & . & . & . & . & . & 6 & . & II & 26 & 13 \\
\hline Marchantia polymorpha "d" & . & . & . & . & 3 & 2 & . & II & 22 & 69 \\
\hline Salix alba "c" & . & . & . & . & . & 5 & . & II & 22 & 11 \\
\hline Calamagrostis epigeios & . & . & . & . & . & 5 & . & II & 22 & 11 \\
\hline Chara sp. & . & 1 & . & . & . & 3 & . & I & 17 & 278 \\
\hline Juncus alpino-articulatus & . & . & . & . & 1 & 3 & . & I & 17 & 28 \\
\hline Alopecurus aequalis & . & . & . & . & 1 & 3 & . & I & 17 & 28 \\
\hline Bidens tripartita & . & . & . & . & 2 & 2 & . & I & 17 & 48 \\
\hline Epilobium adenocaulon & . & . & . & . & . & 4 & . & I & 17 & 8 \\
\hline Daucus carota & . & . & . & . & . & 3 & 1 & I & 17 & 7 \\
\hline
\end{tabular}

\section{RESULTS}

The habitat of Typhetum laxmannii (Ubrizsy 1961) Nedelcu 1968 in Poland

The association of Laxmann reed is an easily distinguishable plant community of rush of medium height. The most suitable habitat conditions for the development of this association occur in the bottom of mineral excavations with shallow waters where the water level fluctuates between 0 and $0,4 \mathrm{~m}$. The significant majority of the phytocoenoses were found in wet shore zones of artificial reservoirs, hollows in the ground and drainage ditches with an unstable water level fluctuating during the year. The highest water level takes place in spring, and in mid-summer the area dries up. The periodic dryness seems not to be harmful to the association and it is similar to the dryness occurring in the habitats of Typha laxmannii in the area of its natural range (e.g. Asia and south-east Europe) as well as to cultivation management on rice fields. The Typhetum laxmannii association in Poland occupies eutrophic habitats with a low content of organic matter - this is analogous to its natural habitats within the river valleys. In most cases, the solum consists of lime, marl or mud pulp (in quarries) or sandy soil (in sand pits and ditches).

The association of Laxmann reed develops in open areas with a high insolation rate. The development of the shrub layer results in an increase in shading which causes a decrease in the density and cover rate of the species. In thick shrubs or high rushes the species occurs rather sporadically and it is characterized by a small population size.
The phytocoenotic relations and distribution of the association

During the field studies in southern Poland the authors have found 14 locations of Typha laxmannii where the species builds its own association - Typhetum laxmannii (Ubrizsy 1961) Nedelcu 1968. The phytosociological characteristic of the association is presented in the tables (Table 1 and 2). On the other known stations, the populations of Laxmann reed are very small, they often consist of only several individuals being an additional component of different plant communities from Phragmitetea R.Tx. Et Prsg 1942 or Charetea (Fukarek 1961) Krausch 1964 classes.

The researched phytocoenoses of Typhetum laxmannii differ from each other in species richness. Between 6 to 20 species occur in the patches of Typhaetum laxmannii associacion and the average species richness within the relevés is 12 . The characteristic feature of the phytocoenoses is the evident dominance of Typha laxmannii and, additionally, the occurrence of species from the following classes: Phragmitetea, Molinio-Arrhenatheretea, Isoëto-Nanojuncetea, Salicetea purpurae and Bidentetea tripartiti. Altogether in the patches of the studied association 80 species were observed. Eight of them are differential species, but only four (Juncus articulatus, Eleocharis palustris, Typha latifolia and Alisma plantago-aquatica) occur with a constancy rate higher than 50\% and a cover index from 398 to 104 (Table 2). In some cases, in oligotrophic conditions with little organic matter (e.g. on the bare and wet bottom of marl quarry in Wierzbica where the most numerous population of Typha laxmannii in Poland have developed) the 


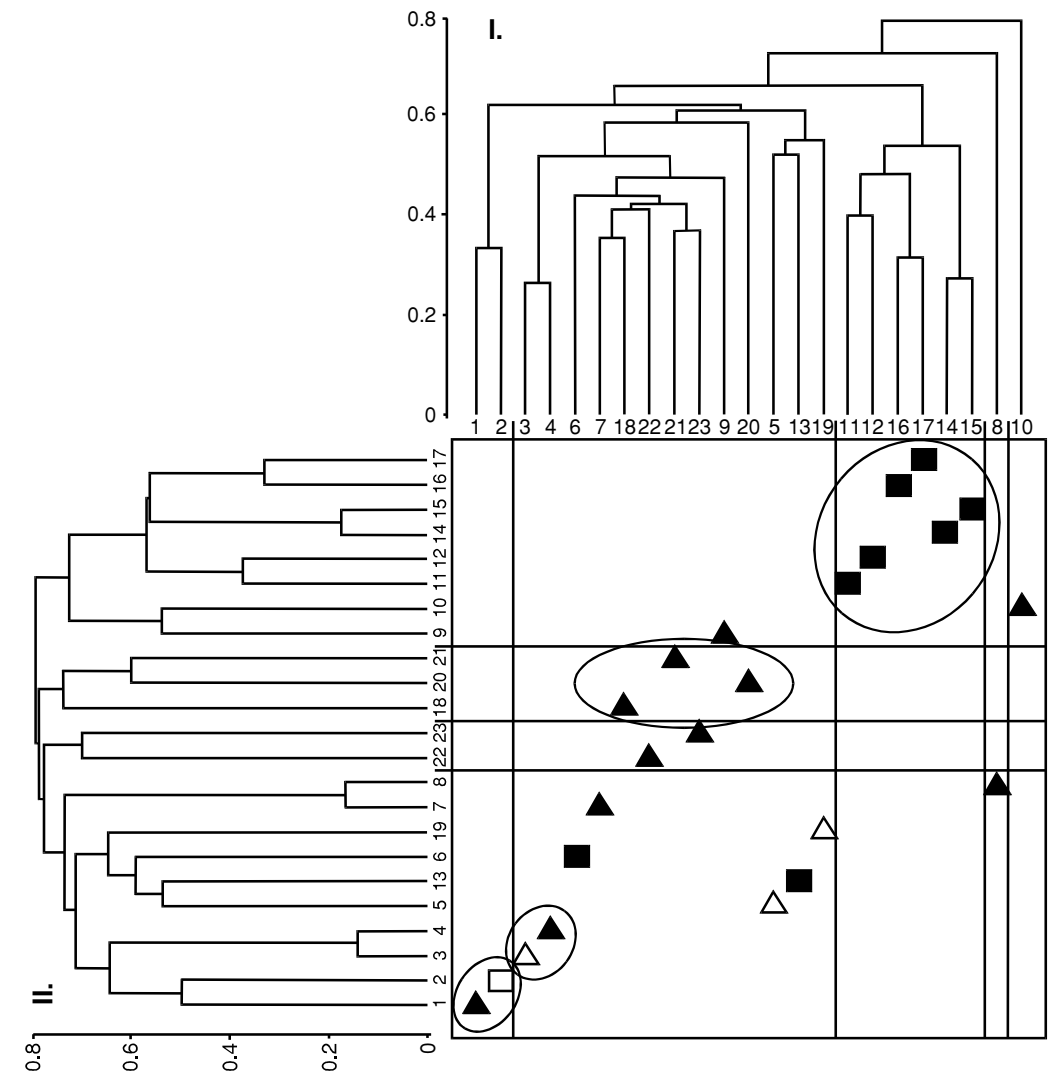

Fig. 2. Classification and dispersion diagram of phytosociological relevés done in the patches of Typhetum laxmannii (Ubrizsy 1961) Nedelcu 1968 within the area of Poland. Dendrogram were constructed on the basis of: I - quantitative data (Braun-Blanquet abundance degrees: $\mathrm{r},+, 1,2,3,4,5$ recalculated as: $0.1,0.5,1,2,3,4,5)$; II qualitative data $(0 ; 1)$. The numbers on dendrogram follows the relevés numbers in phytosociological table and are grouped regarding the units of geographical division of Poland indicated by the symbols: $\boldsymbol{\Delta}$ Małopolska Upland; $\mathbf{\square}$ - Opole Silesia; $\square$ Beskid Niski Mts.; $\triangle$ - Sandomierska Basin
Laxmann reed has built the mono-species assemblages showing its easily distinguishable pioneer character.

Analysing the dispersion diagram (Fig. 2), which was created using the species of significant constancy rate (occurring at least in three relevés in the table), it is noticeable that the relevés create several groups. This is because of the similar species composition of the community patches caused by the edaphic conditions or the geographic localization of the relevés. Remarkably different are the phytocoenoses in Opole Silesia (relevés number 11, 12, 14, $15,16,17)$ and in Małopolska Upland (relevés number 18, $20,21)$. The floristic composition is directly influenced by the soil conditions, mainly the bedrock substratum in excavations (marl, limestone, sand, gravel or other minerals) as well as by the hydrological and drainage circumstances. When the edaphic conditions are similar, even populations occurring in different parts of Poland indicate similar floristic structure, e.g. relevés number 1, 2 and 3, 4. The first pair refers to the populations in the Małopolska Upland and Beskid Niski Mts., whereas the second one refers to the Małopolska Upland and Sandomierz Basin.

\section{Listing of localities}

The listing includes the date of distribution of Typhetum laxmannii (Ubrizsy 1961) Nedelcu 1968 in Poland (Fig. 3). The localities are given in the ATPOL grid (Zając 1978). Capital letters indicate squares in length $100-\mathrm{kms}$ and numbers denote squares $10-\mathrm{kms}$ in length.
CF: 03 - basalt quarry in Ligota Tułowicka; 16 - marl quarries in Kamień Śląski and in Górażdże; 18 - marl quarry in Strzelce Opolskie; 48 - sand pit in Kotlarnia.

DF: 24 - sand pit in Kuźnica Warężyńska near Dąbrowa Górnicza; 46 - the artificial channel of the Jaworznik stream, ca. 2-3 km N from Trzebinia.

EE: 37 - marl quarry, ca. 0,5-1 km NW from Wierzbica; 64 - chalk-pit, Zachełmie near Zagnańsk; 78 - chalk-pit, Skały near Grzegorzowice; 84 - chalk-pit, Kowala, Kowala-Sobków; 91 - excavation, E part of Klimontów near Sandomierz.

FF: 48 - sand pit near San old river-bed, Pigany near Sieniawa; 69 - sand pit, NE part of the Zgoda village near Jarosław.

FG: 35 - chalk-pit Kożuszne near Wysoczany village ( $\mathrm{N}$ from Komańcza).

\section{The syntaxonomic position of the community}

Class: Phragmitetea R.Tx. et Prsg 1942

Order: Phragmitetalia Koch 1926

Alliance: Phragmition Koch 1926

Association: Typhetum laxmannii (Ubrizsy 1961) Nedelcu 1968

\section{CONCLUSIONS}

In the area of Poland, Typhetum laxmannii association presently develops almost exclusively in habitats signifi- 


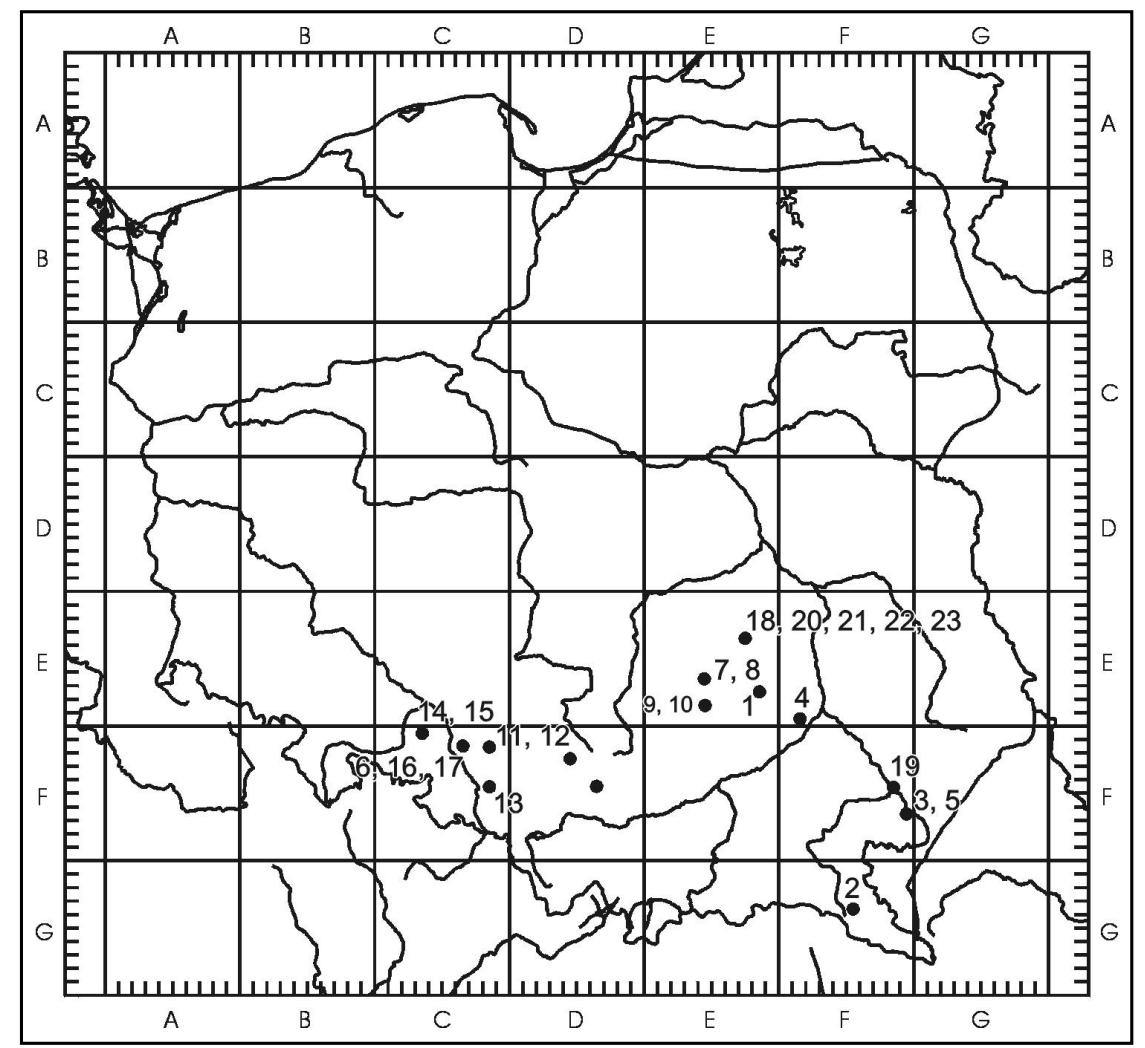

Fig. 3. Distribution of the Typhetum laxmannii (Ubrizsy 1961) Nedelcu 1968 association in Poland (the locations are accompanied by the number of relevé in the phytosociological table-Table 1).

cantly influenced by man. The most suitable conditions for this community occur in different kinds of mineral excavations, especially quarries and sand pits. The community prefers the shore zone of water reservoirs and wet places in drainage ditches and shallow pools. A similar situation is observed in the other countries of Central Europe, e.g. in Slovakia Typha laxmannii was noticed in anthropogenic habitats with almost the same differential species (Ot'ahel'ová et al. 2001) as in Poland. In Romania, alongside the Dudu river where the association was first described, the patches of the association consist of almost $30 \%$ of the species occurring in our country. Other transitional species coming from other communities (in the majority of the species of sporadic character in the diagnostic table - see Nedelcu 1968) are absent in Polish patches of this association because of their different habitat preferences or their geographical range.

It is worth noticing that the conditions occurring in anthropogenic habitats (e.g. quarries and sand pits) where the studied species was found in Poland have many similar features to those existing in natural or semi-natural habitats in the native range of this association. Taking into account the frequency of occurrence of quarries and sand pits in the area of Poland it seems to be very probable that the potential range of the Typhetum laxmannii association will cover the whole southern part of Poland. It may even appear in northern Poland where the climatic conditions are also suitable for Typha laxmannii. The confirmation of this hypothesis is a significant increase of reported locations of the studied species in recent years. It is connected with fast spreading from the area of south-eastern Europe and indi- cates the expansive character of Laxmann reed. The synergic effect of climate warming and mining activities can cause the spread of Typhetum laxmannii into semi-natural and natural ecosystems all over central Europe, which could have serious consequences for their biodiversity.

\section{ACKNOWLEDGEMENTS}

The authors want to thank Dr Adam Stebel for the identification of the moss taxa. We are also very grateful to Prof. Dan Gafta from the University of Cluj-Napoca, Prof. YuLong Feng from the Tropical Botanical Garden, Chinese Academy of Science and Dr Alessandro Alessandrini from the Provincial Office of Bolonia for very useful information. Special thanks we address to Prof. Eugeniusz Dubiel and Prof. Adam Zając for their advice and correction of the manuscript.

\section{LITERATURE CITED}

BALASHEV L.S., PARAKHONSKAJA N.A. 1977. Extension of Typha laxmannii Lepech. area of distribution in the south of the Ukrainian SSR in connection with construction of large canals. Ukr. Bot. J. 34 (6): 612-616.

BARYŁA J., BRÓŻ E., CZYLOK A., MICHALEWSKA A., NIKEL A., NOBIS M., PIWOWARCZYK R., POLOCZEK A. 2005. Typha laxmannii Lepech. the new, expansive kenophyte in Poland: distribution and taxonomy. Acta Soc. Bot. Pol. 74 (1): 25-28.

BECZAŁA T., CHWASTEK E., WIKA S. 2005. Nowe stanowiska chronionych i zagrożonych gatunków roślin naczyniowych 
na Pogórzu Cieszyńskim. Bad. Fizjograf. nad Pol. Zach., ser. B - Botanika, 54: 125-128. (in Polish with English summary)

BISSARDON M. 2000. Corine biotopes. Version originale types d'habitats francaise. Ecole nationale du genie rural, des eaux et des forêts. 26 pp.

CHYTRÝ M., RAFAJOVÁ M. 2003. Czech national phytosociological database: basic statistics of the available vegetationplot data. Preslia 75: 1-15.

COOK C.D.J. 1980. Typha L. In: Flora Europaea. Vol. 5 (Alismataceae to Orchidaceae). T.G. Tutin, V.H. Heywood, N.A. Burges, D.M. Moore, D.H. Valentine, S.M. Walters, D.A. Webb (eds). Cambridge Univessity Press, Cambridge. London, New York, New Rochelle, Melbourne, Sydney, pp. 275-276.

ČVANČARA A., ŠOURKOVÁ M. 1973. Poznamky k rozsireni a variabilite Typha laxmannii Lepech. W Ceskoslovensku. Preslia 45: 265-275 (in Czech with German summary).

CZYLOK A., BARYŁA J. 2003. Notatki florystyczne i ekologiczne z okolic Dąbrowy Górniczej i Sławkowa (Wyżyna Śląska). Natura Silesiae Superioris 7: 11-17. (in Polish)

DEVILLERS-TERSCHUREN J. 2001. Application and development of the Palearctic habitat classification in the course of the setting up of the Emerald Project. Malta. Council of Europe, Strasbourg, $70 \mathrm{pp}$.

DOSTÁL L. 1978. Weitere Fundorte von Typha laxmannii Lepech. in der Ostslovakei. Acta Botanica Slovaca, ser. A, 3: 35-40

FALIŃSKI B. 1969. Zbiorowiska autogeniczne i antropogeniczne. Próba określenia i klasyfikacji. Ekologia Polska Ser. B, 15 (2): 173-179. (in Polish)

FEKETE G., MOLNÁR Z., HORVÁTH F. 1997. A magyarországi élőhelyek leirása, határozója és a Nemzeti Élőhelyosztályozási Rendszer. Budapest, 299 pp. (in Hungarian)

FIALA K., JANKOVSKÁ V. 1968. Typha laxmannii Lepech. nový druh československé květeny. Preslia 40: 192-197. (in Czech with English summary)

GUINOCHET M., DE VILLMORIN R. 1978. Flore de France. Vol. 3. Centre national de la recherche scientifique, Paris, pp. 819-1200.

GUTH J. 2002. Metodiky mapováni biotopů soustavy Natura 2000 a Smaragd. Agentura Ochrany Přirody a Krajiny České Republiky, Praha, 47 pp. (in Czech)

HALACSY E. (ed.) 1902. Conspectus florae Graecae. Vol. 2. Guilelmi Engelmann, Lipsiae, pp. 1-612.

HAYEK A. 1932-1933. Prodromus Florae penninsulae Balcanicae Vol. 3. Verlag des Repertorimus, Berlin, pp. 1-580.

HEUPLER H., MUERT T. 2000. Bildatlas der Farn- und Blütenpflanzen Deutschlands. Verlag Eugen Umler, Stuttgart, pp. 1-759.

HRIVNÁK R. 2004. The plant communities of Phragmitetalia in the catchment area of the Ipel' river (Slovakia and hungary) 1. Reed wetlands (Phragmition communis). Biologia, Bratislava 59 (1): 75-99.

KALIGARIČ M.K., JOGAN N. 1996. Typha laxmannii Lepech., nova vrsta v flori Slovenije. Hladnika 7: 21-28 (in Slovenian with English summary).

KLOKOV V.M., VOLKOVA T.F. 1988. Overgrowth of the Irtysch-Karaganda canal. Gidrobiol. Zh. Kiev. 24 (2): 7-10.

KORNAŚ J. 1981. Oddziaływanie człowieka na florę: mechanizmy i konsekwencje. Wiadom. Bot. 25: 165-182. (in Polish)

MATUSZKIEWICZ W. 2001. Przewodnik do oznaczania zbiorowisk roślinnych Polski. Vademecum Geobotanicum 3. ss. 537. Wydawnictwo Naukowe PWN, Warszawa. (in Polish)

MIREK Z., PIEKOŚ-MIREK H., ZAJAC A., ZAJAC M. 2002. Flowering plants and pteridophytes of Poland - a checklist. In: Z. Mirek (ed.), Biodiversity of Poland 1. p. 442. W. Szafer Institute of Botany, Polish Academy of Sciences, Kraków.

MORISI A. 1998. Studio floristico e vegetazionale sulle aree di riequilibrio ecologico di quattro communi della Provincia di Bologna. 206 pp. (in Italian)

MORISI A. 2001. Aspetti e criteri di natura progettuale per la definizione di massima di interventi di realizazione ambientale del fiume Reno e delle sue pertinenze. Provincia di Bolonia, $14 \mathrm{pp}$. (in Italian)

NEDELCU G.A. 1967. Beiträge zum phytosoziologischen studium des Cernica-Sees. Vegetatio, Vol. XV: 33-50.

NEDELCU G.A. 1968. Notă floristică şi geobotanică a bălti Dudu. Com. Bot. Vol. VII: 66-72. (in Romanian)

NEDELCU G.A. 1969. Flora şi vegetaţia acvatică şi palustră a cîtorva lacuri din cîmpia Română, ce unele consideraţii morfo-ecologice. Rezumatul tezei de doctorat, Universitatea din Bucureşti. 31 pp. (in Romanian)

NOWAK A. 2004. The distribution of Typha laxmannii Lepech. new kenophyte in the Opole Silesia. Opole Sc. Soc., Nature J. 37: 23-28.

OBERDORFER E. 1990. Pflanzensoziologische Excursions Flora. Eugen Umler Verlag, Stuttgart, pp. 1050.

OCHYRA R., ŻARNOWIEC J., BEBNAREK-OCHYRA H. 2003. Census Catalogue of Polish Mosses. In: Biodiversity of Poland 3, Z. Mirek (ed.), p. 372. W. Szafer Institute of Botany, Polish Academy of Sciences, Kraków.

ORI R., ALAGNA F. (eds) 2004. Agenda strategica per la sviluppo della rete ecologica. Centro Agricultura Ambiente, Modena, 75 pp. (in Italian)

OT'AHEL'OVÁ H., HRIVNÁK R., VALACHOVIČ M. 2001. Phragmito-Magnocaricetea. In: Rastlinné spoločenstvá Slovenska. M. Valachovič (ed.) 2001. pp. 51-184. Veda vydavatel'stvo akadémien vied Bratislava. (in Slovakian)

PAWŁOWSKI B. 1977. Skład i budowa zbiorowisk roślinnych oraz metody ich badania. In: Szata roślinna Polski. Szafer In:, Zarzycki K. (eds), v. I. PWN Warszawa: 237-268. (in Polish)

PIGNATTI S. 1982. Flora d'Italia. Vol. 3. Edagricole, Bologna, pp. 1-780 (in Italian).

POPESCU A., SANDA V., NEDELCU G.A. 1969. Cenotaxonomia şi structura grupărilor de macrofite ale clasei Phragmitetea Tx. Et. Prsg. 42 din România. Acta Botanica Horti Bucurestiensis, Extras: 63-82. (in Romanian)

POPOVA E.N. 2003. Flora and vegetation of Kiliya delta of Danube river. Wisnik Odeskowo Nacjonalnowo Uniwersiteta 8(11): 106-137. (in Ukrainian with English summary)

PROKUBIN J.U.N. (ed.) 1987. Opredelitel' wysszich rastienij Ukrainy. Kijew, Naukova Dumka, pp. 456 (in Russian).

ROZLOZNIK M. 1998. Biosfericka rezervacia Slovensky kras z pohladu jej dvadsatrocneho trvania. Zivot. Prostr. 32 (1): 21 -32. (in Slovakian)

SARIKA M., DIMOPOULOS P., YANNITSAROS A. 2005. Contribution to the knowledge of the wetland flora and vegetation of Amvrakikos Gulf, W Greece. Willdenowia 35: 69-85.

SNEATH P.H.A., STOKAL R.R. 1973. Numerical taxonomy. The principles and practice of numerical classification. Freeman a. Comp., San Francisco, pp. XV+573.

STOJANOV N., STEFANOV B. 1948. Flora na Bulgarii. Sofia, Universiska Pečatnica, pp. 1361.

ŠUMBEROVÁ K., CHYTRÝ M., SÁDLO J. 2001. Rákosiny a vegetace vysokych ostřic. In: Katalog biotopů České republiky. M. Chytrý, T. Kučera, M. Koči (eds). Praha, 24 pp. (in Czech).

SZMALHAUSEN J. 1897. Flora Sredniej i Jużnoj Rossij. Vol. 2. Kijev', pp. XIV, 752. (in Russian).

TOPIC J., OZIMEC S. 2001. Typha laxmannii Lepechin (Typhaceae), new species in the Croatian flora. Nat. Croat., 10 (1): 61-65.

UBRIZSY G. 1961. Unkrautvegetation der reiskulturen in Ungarn. Acta Bot. Acad. Sci. Hung, 7: 175-220.

WOCH M. 2005. Rozprzestrzenianie sie nowego kenofita Typha laxmannii (Typhaceae) na Wyżynie Śląskiej. Fragm. Flor. Polon. 12 (1): 176-179. (in Polish with English summary)

ZAJAC A. 1978. Atlas of distribution of vascular plants in Poland (ATPOL). Taxon 27 (5/6): 481-484. 